\title{
Study of potential application of alternative power cycles in colombia
}

\section{Estudio de la potencial aplicación de ciclos de potencia alternativos en Colombia}

\author{
Mawency Vergel Ortega ${ }^{1}$ \\ Jhan Piero Rojas Suarez ${ }^{2}$ \\ 'Sofia Orjuela Abril ${ }^{3}$ \\ Universidad Francisco de Paula Santander, \\ Cúcuta, Colombia
}

\begin{abstract}
The energy cost and environmental problems such as greenhouse gas emissions have made efficient energy and renewable energy resources use a necessity for the care of the environment and for the economic and productive growth of the different sectors of a country's economy. This has been achieved through policies that encourage the application of technologies that increase the processes efficiency and take advantage of the means available for generating power in different

1 Departamento de Matemáticas y Estadística, Universidad Francisco de Paula Santander, Norte de Santander, Cúcuta, Colombia, correo: mawencyvergel@ufps.edu.co Orcid: https://orcid.org/0000-0001-8285-2968

$2 \quad$ Facultad de Ingenierías, Universidad Francisco de Paula Santander, Cúcuta, Colombia. Correo jhanpierorojas@ufps.edu.co ORCID iD: https://orcid.org/0000-00032682-9880

$3 \quad$ Facultad de Ciencias Empresariales, Universidad Francisco de Paula Santander, Cúcuta, Colombia. Correo: sofiaorjuela@ufps.edu.co ORCID: https://orcid.org/00000002-9742-8673
\end{abstract}

sectors of the economy where alternative power cycles like Goswami, Kalina, and ORC have great potential in both energy recovery and the use of renewable energy resources. In Colombia, the potential for using these technologies is wide in the industry since sectors such as Steel, cement, textile, among others, are made up. Where these cycles represent an opportunity for efficient energy use and, on the other hand, in the use of renewable energies such as geothermal and solar, these cycles have again proven to be viable, and due to the geographical location and characteristics of its soil, Colombia has a wide potential. All this shows the necessity for national policies that encourage efficient use through subsidies, investment, training, etc. For the application of alternative power cycles because their costs are so high and 
the support of financing instruments and policies at the national level is a latent need in Colombia.

\section{KEYWORDS:}

Alternative Cycles, Efficiency Energy, Energy Policy, Potential, Renewable Energy.

\section{RESUMEN}

El costo de la energía y los problemas ambientales como las emisiones de gases de efecto invernadero han hecho que el uso eficiente de la energía y de los recursos energéticos renovables sea una necesidad para el cuidado del medio ambiente y para el crecimiento económico y productivo de los diferentes sectores de la economía de un país. Esto se ha logrado a través de políticas que incentiven la aplicación de tecnologías que aumenten la eficiencia de los procesos y aprovechen los medios disponibles para la generación de energía en los diferentes sectores de la economía donde los ciclos alternativos de potencia como Goswami, Kalina y ORC tienen un gran potencial tanto en la recuperación de energía como en el uso de recursos energéticos renovables. En Colombia, el potencial de uso de estas tecnologías es amplio en la industria ya que se conforman sectores como el Acero, el cemento, el textil, entre otros. Donde estos ciclos representan una oportunidad para el uso eficiente de la energía y, por otro lado, en el uso de energías renovables como la geotérmica y la solar, estos ciclos han demostrado nuevamente ser viables, y por la ubicación geográfica y características de su suelo, Colombia tiene un amplio potencial. Todo esto muestra la necesidad de políticas nacionales que incentiven el uso eficiente a través de subsidios, inversión, capacitación, etc. Para la aplicación de los ciclos alternativos de energía por sus altos costos y el apoyo de instrumentos y políticas de financiación a nivel nacional es una necesidad latente en Colombia.

\section{PALABRAS CLAVE:}

Ciclos alternativos, Eficiencia energética, Política energética, Potencial, Energías renovables.

\section{INTRODUCTION}

The efficiency of energy use is a current necessity, and the world has this course due to various factors. One of them is the growing trend of energy demand. U.S Energy Information Administration published a projection of $50 \%$ growth in energy use between 2018 and 2050. Other factors are sustainability, energy security, distribution, among other factors derived from the use of non-renewable primary energy. However, the use of non-renewable primary energy has been fundamental for world economic development (Hook \& Tang, 2013). In addition, it has brought negative effects that have been reflected in recent decades. Such as global warming due to the high emission of greenhouse gases (GHG), studies estimate an increase in GHG emissions from $25 \%$ to $90 \%$ between 2000 and 2030 (IPCC, 2008).

Methods and new technologies are being implemented for the recovery of waste energy (Broberg \& Johansson, 2014). With this, a great environmental and economic impact has been achieved. This is the reason why the application of power generation systems through alternative thermal cycles such as Kalina, Organic Rankine (ORC), and Goswami (Karimi M., Dutta, Kaushik, Bansal, \& Haque, 2015) (CASATI, 2014) has been considered an important option for efficient energy use and this energy problem mitigation (Broberg Viklund \& Johansson, 2014).

In the energy recovery area, the industry potential is vast. (Hammond \& Norman, 2014) estimated $52 \mathrm{PJ} / \mathrm{yr}$ in the industrial sector in the UK and found that the greatest potential is in low-temperature waste energy, where ORC is the most common. R.C. (McKenna \& Norman, 
2010)estimated the energy recovery potential of $36-71 \mathrm{PJ} / \mathrm{yr}$ for the industry in the same country. In 2012 it was estimated 4GWe in the cement industry of waste energy with $49 \%$ of total potential corresponding to heat at low temperatures, $60 \%$ in Steel industry with a total potential estimated of 2.9 GWTh (Lu, 2015). (Broberg Viklund \& Johansson, 2014) calculated $25 \mathrm{GWh} /$ year of electricity or $91 \mathrm{GWh} /$ year of district heating using excesses of thermal energy with the technologies proposed in Gävleborg, Sweden. (Bailey \& Worrel, 2005)estimated the potential for energy recovery of $750 \mathrm{MWe}$ in the USA, $500 \mathrm{MWe}$ in Germany, and $300 \mathrm{MWe}$ in Europe.

By another hand, Studies have (Haddad, Périlhon, Danlos, François, \& Descombes, 2014) determined that the highest percentage of waste energy is in low-temperature ranges between $100-200^{\circ} \mathrm{C}$. This is why in this area, these cycles have been quite studied and used. One of the most widely used cycles is the ORC, which has proven to be an efficient cycle for power generation with low-temperature sources (Yamada, Tominaga, \& Yoshida, 2014). Lemmens y Lecompte (Lemmens \& Lecompte, 2017) studied an application case of a Rankine organic cycle (ORC) in energy recovery in the Flanders region, Belgium. Kwak, Binns, and Kim (Kwak, Binns, \& Kim, 2014) have investigated several scenarios for ORC implementation. Kalina proposed a thermodynamic cycle for energy recovery that has his name (Kalina A., Combined cycle and waste heat recovery power systems based on a novel thermodynamic energy cycle utilizing low-temperature, 1983). Paredes et al. (Paredes Sanchez, Restrepo Baena, Álvarez Rodríguez, Osorio Correa, \& Restrepo, 2015) studied energy recovery in the Portland cement industry.

\section{METHOD}

In the energy use of renewable sources, these cycles have been widely used and studied.
Wolpert et al. (Wolpert \& Riffat, 1996) used ORC for domestic applications taking advantage of solar energy in the UK and Mexico. Kalina and Leibowitz (Kalina \& Leibowitz, Application of the Kalina cycle technology to geothermal power generation, 1989) presented a Kalina cycle application using geothermal energy. Lolos et al. (Lolos \& Rogdakis, 2009)studied the Kalina application powered by solar collectors. Cheng et al. (Cheng, Sanjayan, \& Amer, 2005) studied ORC use to produce at least $10 \mathrm{MW}$ with solar energy in Malaysia.

Considering the review of the art state, there is no doubt about the potential of using power cycles for efficient energy use, climate change, and, therefore, the economic benefits that this brings. Also, we can observe the necessity to create and implement public policies that promote efficient energy use in order to promote the development of systems of this type and thus mitigate the environmental energy problem that is projected for the following decades. Relatively demanding measures have already been taken in different countries through public policies. Encouraging and promoting laws, training, subsidies, among others. Unfortunately, even so, be aware, not all government states have progressed in the same way in terms of efficient energy use, as happens, for example, at the national level, even so, having a great energy potential.

The energy policies that favor the implementation and development of the energy recovery power cycles in Colombia are implemented by the Ministry of Mines and Energy (MME). An entity whose main objective is to formulate and adopt timely policies, plans, programs, projects, and regulations for the mining and energy sector, in accordance with the guidelines of the National Government (Ministerio de minas y energía, s.f.). In Colombia, we have some laws and decrees that enhance the technologies application for alternative energy development. 
In 2001, Law 697 was issued, in which rational and efficient energy use is promoted, the use of alternative energy is encouraged, and other provisions are issued. In order to progress, through this law, the rational energy use program (PROURE) was created by MME (Law 697), regulated by decree 3683 of 2003 and the intersectoral Commission for the rational and efficient use of the energy and unconventional energy sources (CIURE) (Decree 3683 of 2003). Decree was modified in 2008 by decree number 2688 (Decree 2688 of 2003).

Legal entities that directly make investments in control, conservation, and improvement of the environment will have the law to deduct $25 \%$ of the investments they have made in the respective taxable year from their income tax (article $255 \mathrm{ET}$ ). Exemption from taxes on the import of machinery and equipment for projects development or activities that are exporters of certificates of carbon emissions reduction and that contribute to reducing greenhouse gas emission and, therefore, to sustainable development (Article 428 lit i).

By law 1715 of 2014, incentives for investment in non-conventional energy source projects (FNCE) are established, such as accelerated depreciation of assets applied to the machinery, equipment, and civil works necessary for the pre-investment, investment, and operation of the generation with FNCE, that are acquired and/ or built, exclusively for that purpose, from the effective date of this law. For these purposes, the annual depreciation rate will be no more than twenty percent $(20 \%)$ as the annual global rate (Article 14).

In addition, this law promotes the development of energies from Biomass, solar, geothermal energy, among others. In which the alternative cycles of power generation have an application (Law 1715 of 2014).

\section{RESULTS AND DISCUSSION}

\subsection{KALINA CYCLE}

Alexander Kalina proposed a group of the cycle which use ammonia-water mixture like a working fluid (United Estate Patente $\mathrm{n}^{\circ}$ 4346561, 1982) (Kalina A., Combined cycle and waste heat recovery power systems based on a novel thermodynamic energy cycle utilizing low-temperature for power generation, 1983a) (Kalina A., Combined-cycle system with novel bottoming cycle, 1984). This cycle was thought to improve efficiency and installation cost per kilowatt at that moment (Kalina A., Combinedcycle system with novel bottoming cycle, 1984). The main feature of this family of cycles is the working fluid, and this mixture allows work with different conditions for several reasons. One of them is because the composition of the mixture could be fixed (Ogriseck, 2009) that make this cycle more flexible, and in some case is necessary a separator that facilities a working range. Ammonia-water mixture has thermophysical properties like variable boiling temperature, which can thus be fitter to the falling temperature of heat source that results in a reduction entropy generation (Valdimarsson \& Eliasson, 2003) and allow capture more of available potential work (Mlcak, 2002).

Cycles with these characteristics have been developed for several operational conditions. We can find various Kalina Cycle System (KCS). The first one published by Kalina (Kalina A., Combined-cycle system with novel bottoming cycle, 1984) was designated as KCS 1. KCS 6 was developed as an improved variant with an increase of $10 \%$ in efficiency (Kalina A., Novel power cycle for combined-cycle system and utility power plants(ESL-IE-86-06-39), 1986). We can find KCS 34 and KCS $34 \mathrm{~g}$, which are suitable for temperatures below $121^{\circ} \mathrm{C}$ (Mlcak, 2002). KCS $34 \mathrm{~g}$ is suitable for smaller size plants, while KCS 34 is used for combined power production and downstream district heating applications (Mlcak, 
2002). We can find several designs in literature for different conditions and applications, and the most common application is geothermal energy, but the Kalina cycle is not just for geothermal energy. KCS 1-2 is an option to heat recovery in a cement kiln (Mirolli, Cementing Kalina cycle effectiveness, The Kalina Cycle for cement klin waste-heat-recovery power plants, 2006) which has shown better results than organic Rankine cycle, although in energy recovery, this is better.

\subsection{GOSWAMI CYCLE}

This cycle was created by Dr. Yogi Goswami in 1998. It is characterized by being a combination of the Rankine power cycle and an absorption power cycle (Karimi M., Dutta, Kaushik, Bansal, \& Haque, 2015). Also, its working fluid is an ammonia and water mixture, which reduces the heat transfer irreversibilities, especially for lowtemperature finite heat sources such as heat from solar collectors and geothermal heat (Feng, Goswami, \& Sunil, 2000).

A series of benefits or advantages that can be obtained with this cycle can be the production of energy and cooling in the same cycle, efficient conversion of heat sources of moderate temperature, in addition, the possibility of improved resource utilization compared to separate power and cooling systems (Karimi M., Dutta, Kaushik, Bansal, \& Haque, 2015)

Comparative studies with the Rankine cycle showed a $10-20 \%$ improvement in thermal efficiency (Maloney \& Robertson, 1953). Following this, another study carried out shows that the cycle proposed by Goswami preserves the advantages of the Kalina cycle but eliminates the restrictions that the Kalina cycle presents (Feng, Goswami, \& Sunil, 2000).

\subsection{ORGANIC RANKINE CYCLE (ORC)}

The Organic Rankine Cycle is the most common candidate for waste heat recovery and is considered a mature technology (Oluleye,
Jobson, Smith, \& Perry, 2016) (Crook, 1994). This cycle is a variation of the Rankine cycle, which uses an organic fluid as work fluid (Devotta \& Holland, 1985) that allows operation with a low-temperature heat source. Moreover, ORC has some benefits like low maintenance costs and desirables operating pressures (Tchance, Lambrinos, Frangoudakis, \& Papadakis, 2011).

Fluid selection is an important parameter in the design of ORC. A good selection of work fluid has a greater influence on performance and output net power (Javanshir \& Sarunac, 2017). And each application and operational condition determines the correct work fluid (Freeman, Hellgardt, \& Markides, 2015) (Desai \& Bandyopadhyay, 2016) (Drescher \& Brüggemann, 2007).

\subsection{COMPARATIVE ANALYSIS WITH EUROPEAN UNION AND U.S.A.}

The European Union developed the Europe 2020 strategy, where the European Commission aims to $20 \%$ of reduction in GHG, an increase of $20 \%$ of renewable energy production, and an increase of $20 \%$ in energy efficiency compared to 1990 . This objective was proposed for 2020 (EC. Europe 2020, s.f.). In 2014 the efficiency target was changed by $27 \%$ in 2030 . In 2018 was fixed a $32.5 \%$ by 2030 in a reduction of energy consumption, which was an energy efficiency target. All these proposals focused on economic growth, a European sustainable and eco-friendly, and obtained good results with a decreasing ODEX index in Household, Transport, Services, and Industry (Ciucci), as we can see in Figure 1.

In 2012 European Union published an act that is mainly for efficient energy use (Directive 2012/27/EU of the European Parliament and of the Council of 25 October 2012 on energy efficiency, 2012). 
Figure 1: ODEX index in Europe Union (European environment agency, s.f.).

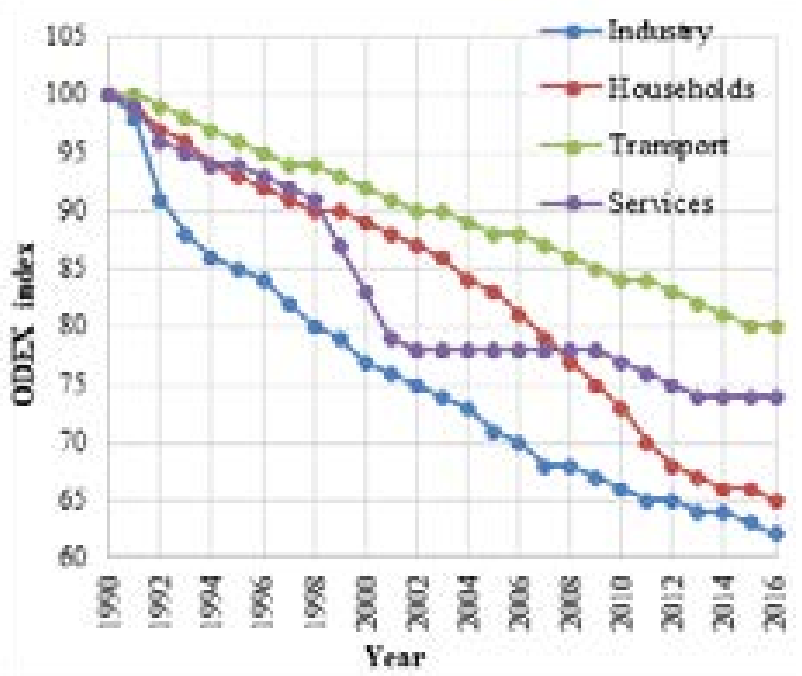

In this act (Directive 2012/27/EU of the European Parliament and of the Council of 25 October 2012 on energy efficiency, 2012), article 12 established a group of instruments and policies to promote the change, and these ones include fiscals incentives, access to finance, subsidies, workplace activities, an exemplary project. On the other hand, Article 14 promotes efficiency in heating and cooling. Moreover, paragraph 11 of this article promotes the use of waste heat for energy production with the objective of saving primary energy, and additionally, paragraphs 35 and 36 of the act talk about waste heat recovery.

This directive covered some technologies for energy recovery or cogeneration and include ORC, a combined cycle gas turbine with heat recovery, a gas turbine with heat recovery, and any other technology that meet the definition of cogeneration established by the act in Paragraph 30 in article 2.

This directive was a significant advance in the promotion of alternative cycles to heat recovery and efficient energy use. This produced developed in the application of these technologies. An example is Germany, where the federal government establishes goals of electric generation by cogeneration or heat waste recovery, as we can see in Figure 2.

Figure 2: Electricity production by CHP in Germany (Umwelt bundesamt, s.f.).

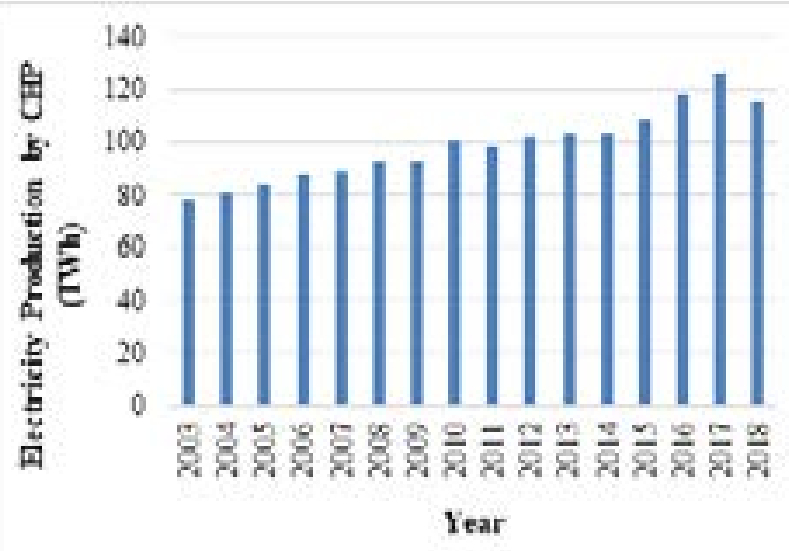

The U.S. Department of Energy Efficiency \& Renewable Energy (EERE) has established some objectives to increase efficiency energy use. They aim $25 \%-50 \%$ of energy saving by 2020 -2030 in homes, buildings, and industries (Energy efficiency and renewable energy, s.f.).

In the United States, each state has a group of incentives by efficiency energy use and renewable energy. From household to industry. We can find subsidies, credits to investment, energy credits, and other ones (DSIRE, s.f.). Through the Energy Policy Act of 2005, the United States promotes the use of geothermal energy where Kalina, ORC, and Goswami could be used. With the Energy Policy Act of 1992, the United States promotes energy efficiency in all countries. Where ORC, Kalina, and Goswami could be used in heat recovery.

\subsection{ENERGETIC POTENTIAL FOR ALTERNATIVE CYCLES POWER USE IN COLOMBIA}

Observing the last Colombian energy balance, carried out by UPME in 2015, wasted energy costs of close to 4.7 billion dollars a year, it is clear that the theoretical potential of Colombia to improve energy efficiency is significant (UPME, 
2016). As can be seen in Figure 3, the greatest energy demand is destined for the transport sector and the energy sector, being here where the greatest losses are generated.

Figure 3: Distribution of final energy consumption in Colombia (UPME, 2016).



The Colombian industry is mainly made up of sectors such as manufacturing, textile, cement, steel, ceramics, etc., in which energy consumption is high due to the productive process of each sector. Each of these, where heat demand is high, are possible areas of application for alternative cycles as an option to make the Colombian industry more efficient and competent.

In the cement industry, production processes represent approximately 40\% (Moya, Pardo Garcia, \& Mercier, 2011) of the product cost, where $90 \%$ from $40 \%$ correspond to heat in the drying process (Kermeli, Worrell, \& Masanet, 2008). Therefore, strengthening the efficiency of the production process with a focus on waste heat recovery is important to the improvement of the industry

The Kalina and ORC cycle has been studied (Barbosa, Ponce , Ponce, \& Ferreira, 2019) (Moreira \& Arrieta, 2019)(Paredes Sanchez, Restrepo Baena, Álvarez Rodríguez, Osorio Correa, \& Restrepo, 2015) for its use in the recovery of waste heat as an option for energy use. These studies have determined to promise the use of these technologies, which represents an opportunity for energy use for alternative power cycles where this energy can be harnessed and thus increase efficiency significantly in the production process in Colombia.

The metal casting represents 10\% (UPME-BRP, 2007)of the energy consumed in the Colombian industry, where $84.7 \%$ corresponds to thermal energy used in the process (UPME, Acciones y perspectivas en eficiencia energetica, 2014). In Colombia, a study was carried out analyzing 5 foundry businesses in the Valle del Cauca and Cauca. in which they propose the option for organic Rankine cycle application (Carabali, Forero, \& Cadavid, 2018).

In the transport sector, studies have been carried out, applying power cycles for energy recovery. Through the Rankine cycle, ways have been found to optimize and take advantage of waste heat in vehicles (Macián, Serrano, Dolz, \& Sánchez, 2013) in order to reduce energy losses that are reflected in economic losses for the country. Colombia loses approximately 3,000 million dollars per year in this sector due to the inefficiency of the predominant equipment and technologies (UPME, 2016).

From another energy perspective, $73 \%$ of our energy consumption comes from fossil sources. We have crude oil reserves until 2024 and gas reserves until 2029. One of the main objectives is to increase the capacity to generate clean energy as stipulated in the country's national development plan (Duque, 2018). Among these clean energy sources are geothermal energy and solar energy, where alternative power cycles have a great application for the use of energy resources (Tchanche, Pétrissans, \& Papadakis, 2014) (Kalina \& Leibowitz, Application of the Kalina cycle technology to geothermal power generation, 1989), being these a viable option for the energy improvement of the country. 
The applicability potential of these alternative power cycles for growth in efficient energy use can be observed. What represents the different sectors of the country more international competitiveness. Colombia requires the use of technologies that propel it to be a more efficient and productive country, and these cycles represent a step to achieve it.

\section{CONCLUSIONS}

It can be concluded that the application of power cycles such as Kalina, ORC, and Goswami are viable for the mitigation of the energy and environmental problem that is being experienced in the world. In addition, these cycles are a good option to boost the economic development of a country in the most demanding energy sectors, such as industrial and transport.

Colombia is a country with great energy potential that has not yet been exploited in the use of alternatives cycles of power generation. Due to its geographical location, soil, and climates characteristics, it has a renewable natural resource and an industry with the capacity to be developed efficient energy use that makes it an attractive place for the use of alternative cycle as Kalina, ORC, and Goswami.

Energy policies that promote efficient energy and the renewable energies use are so important and necessary for the development of a country because they potentiate and incentivize the investment of companies and investors in the development of expensive energy projects, benefiting the country, the investment entity, and all those who would enjoy the energy quality.

Globally, not all countries have advanced in the same way in terms of developing public energy policies. Some countries, including the European Union, have faced the energy issue with greater commitment. On the other hand, Colombia has relatively extensive environmental legislation.
However, it has not been enough to control energy losses and greenhouse gas emissions, a problem with a negative impact that could collapse in a couple of years.

\section{BIBLIOGRAPHIC REFERENCES}

Bailey, O., \& Worrel, E. (2005). Clean Energy Technologies A Preliminary Inventory of the Potential for Electricity Generation. Enerst Orlando Lawrence Berkeley National Laboratory.

Broberg Viklund, S., \& Johansson, M. (2014). Technologies for utilization of industrial excess heat: Potentials for energy recovery and $\mathrm{CO} 2$ emission reduction. Energy Conversion and Management, 369-379.

Broberg, S., \& Johansson, M. (2014). Technologies for utilization of industrial excess heat; Potentials for energy recovery and $\mathrm{CO} 2$ emisson reduction. Energy Conversion and Management, 369-379.

CASATI, E. I. (2014). New concepts for organic Rankine cycle power systems.

Cheng, E., Sanjayan, V., \& Amer, D. (2005). Solar thermal organic Rankine cycle as a renewable energy option. Jurnal Mekanikal, 68-77.

Ciucci, M. (n.d.). Fact Sheets on the European Union. Retrieved from https://www.europarl. europa.eu/factsheets/en/sheet/69/energyefficiency

Crook, A. (1994). Profiting from low-grade heat. The Watt Committee on Energy Report.

Desai, N., \& Bandyopadhyay, S. (2016). Thermoeconomic analysis and selection of working fluid for solar organic rankine cycle. Applied Thermal Engineering, 471-481. 
Devotta, S., \& Holland, F. (1985). Comparison of Theoretical Rankine Power Cycle Performance Data For 24 Working Fluids. Heat Recovery Systems, 503-510.

Directive 2012/27/EU of the European Parliament and of the Council of 25 October 2012 on energy efficiency. (2012). Retrieved from https://eur-lex.europa.eu/legal-content/EN/ TXT/?uri=celex\%3A32012L0027

Drescher, U., \& Brüggemann, D. (2007). Fluid selection for the Organic Rankine Cycle (ORC) in biomass power and heat plants. Applied Thermal Engineering, 223-228.

DSIRE. (n.d.). Retrieved from https://www. dsireusa.org/

Duque, I. (2018). Plan nacional de desarrollo 2018-2022.

EC. Europe 2020. (n.d.). Retrieved from http:// ec.europa.eu/europe2020/europe-2020-ina-nutshell/targets/index_en.htm

Energy efficiency and renewable energy. (n.d.). Retrieved from https://www.energy.gov/ eere/about-office-energy-efficiency-andrenewable-energy

European environmet agency. (n.d.). Retrieved from https://www.eea.europa.eu/dataand-maps/indicators/progress-on-energyefficiency-in-europe-3/assessment

Feng, X., Goswami, Y., \& Sunil, S. (2000). A combined power/cooling cycle. Energy , 233-246.

Freeman, J., Hellgardt, K., \& Markides, C. (2015). An assessment of solar-powered organic Rankine cycle systems for combined heating and power in Uk domestic applications. Applied Energy, 605-620.

Global Cement. (2012, August 6). Retrieved from https://www.globalcement.com/magazine/ articles/721-kalina-cycle-power-systemsin-waste-heat-recovery-applications

Haddad, C., Périlhon, C., Danlos, A., François, M.-X., \& Descombes, G. (2014). Some efficient solutions to recover low and medium waste heat: competitiveness of the thermoacoustic technology. Energy Procedia, 1056-1069.

Hammond, G., \& Norman, J. (2014). Heat recovery opportunities in UK industry. Applied Energy, 387-397.

Hook, M., \& Tang, X. (2013). Depletion of fossil fuels and anthropogenic climate change. Energy Policy, 797-809.

INMIS energy. (n.d.). Retrieved from http://www. inmis-energy.com/5-0-heat-recovery/52-industrial-applications/5-2-2-selectedreferences

International energy agency. (2019). Retrieved from World Energy Outlook 2019: https:// www.iea.org/reports/world-energyoutlook-2019/energy-efficiency

IPCC. (2008). Cambio climatico 2007. Ginebra, suiza.

Javanshir, A., \& Sarunac , N. (2017). Effect of Working Fluid on Performance of the ORC and Combined Brayton/ORC Cycle. ASME.

Kalina, A. (1982). United Estate Patent No. 4346561.

Kalina, A. (1983). Combined cycle and waste heat recovery power systems based on a novel thermodynamic energy cycle utilizing low-temperatura. ASME.

Kalina, A. (1983a). Combined cycle and waste heat recovery power systems based on a novel thermodynamic energy cycle utilizing low-temperature for power generation. ASME, 1-5. 
Kalina, A. (1984). Combined-cycle system with novel bottoming cycle. ASME.

Kalina, A. (1986). Novel power cycle for combined-cycle system and utility power plants(ESL-IE-86-06-39). Proceedings from the eighth annual industrial energy technology confenrece, Houston, TX.

Kalina, A., \& Leibowitz, H. (1989). Application of the Kalina cycle technology to geothermal power generation. Getehermal Resource Council Trans, 605-611.

Karimi, M., Dutta, A., Kaushik, A., Bansal, H., \& Haque, S. (2015). A Review of Organic Rankine, Kalina and Goswami Cycle . International Journal of Engineering Technology, Management and Applied Sciences, 90-105.

Karimi, M., Dutta, A., Kaushik, A., Bansal, H., \& Haque, S. (2015a). A Review of Organic Rankine, Kalina and Goswami Cycle. IJETMAS, 90-105.

Kwak, D.-H., Binns, M., \& Kim, J.-K. (2014). Integrated design and optimization of technologies for utilizing low grade heat in process industries. Applied Energy, 307322.

Lajorla, J. (1995). Electricity from industrial waste heat using high-speed organic Rankine cycle(ORC). International journal of production economics, 227-235.

Lemmens, S., \& Lecompte, S. (2017). Case study of an organic Rankine cycle applied for excess heat recovery: Technical, economic and policy matters. Energy Conversion and Management, 670-685.

Lolos, P., \& Rogdakis, E. (2009). A Kalina power cycle driven by renewable energy soruces. Energy, 457-464.

Lu, H. (2015). Capturing the invisible Resource:
Analysis of Waste HEat Potential in Chinese Industry and Policy Options for Waste Heat to Power Generation. Ernest Orlando Lawrence Berkeley National Laboratory.

Macián, V., Serrano, J., Dolz, V., \& Sánchez, J. (2013). Methodology to design a bottoming Rankine cycle, as a waste energy recovering system in vehicles. recovering system in vehicles. Study in a HDD engine. Applied Energy, 758-771.

Maloney, J., \& Robertson, R. (1953). Thermodinamic study of ammonia-water heat power cycles. Oak Ridge National Lab.

McKenna, R., \& Norman, J. (2010). Spatial Modelling of industrial heat loads and recovery potentials in the UK. Energy Policy, 5878-5891.

Ministerio de minas y energía. (n.d.). Retrieved from https://www.minenergia.gov.co/ mision-y-vision

Mirolli, M. (2006). Cementing Kalina cycle effectiveness, The Kalina Cycle for cement klin waste-heat-recovery power plants. IEEE Industry Applications Magazine.

Mirolli, M. (n.d.). The Kalina cycle for cement kiln waste heat recovery power plants.

Mlcak, H. (2002). Kaline cycle concept for low temperature geothermal. Geothermal Resources Council transaction.

Ogriseck, S. (2009). Integration of Kaline cycle combined heat and power plant, a case study. Applied Thermal Engineering, 28432848.

Oluleye, G., Jobson, M., Smith, R., \& Perry, S. (2016). Evaluating the potential of process sites for waste heat recovery. Applied Energy. 
Paredes Sanchez, J. P., Restrepo Baena, O. J., Álvarez Rodríguez, B., Osorio Correa, A. M., \& Restrepo, G. (2015). Using waste energy from the Organic Rankine Cycle cogeneration in the Portland cement industry. DYNA, 15-20.

Salazar, S., Muñoz, Y., \& Ospino, A. (2017). Analysis of geothermal energy as an alternative source for electricity in Colombia. Salazar et al. Geotherm Energy, 5-27.

Tchance , B., Lambrinos, G., Frangoudakis, A., \& Papadakis, G. (2011). Low-grade heat conversion into power using organic Rankine cycles - a weview of various applications. Renew Sustain Energy Rev.

Tissot, R. (2012). Latin America's Energy Future. Inter-American Development Bank.

TURBODEN clean energy ahead. (n.d.). Retrieved from https://www.turboden.com/ solutions/1053/waste-heat-recovery

Umwelt bundesamt. (n.d.). Retrieved from https://www.umweltbundesamt.de/en/ indicator-combined-heat-power-chp\#at-aglance

UPME. (2016). Plan de acción indicativo de eficiencia energetica. Bogotá.

Valdimarsson, P., \& Eliasson, L. (2003). Factors influencing the economics of the Kalina power cycle and situacions of superior performance. International Geothermal Conference.

Wolpert, J., \& Riffat, S. (1996). Solar-Powered Rankine system for domestic applications. Applied Thermal Engineering, 281-289.

Yamada, N., Tominaga, Y., \& Yoshida, T. (2014). Demostration of $10-\mathrm{Wp}$ micro organic Rankine cycle generator for low-grade heat recovery. Energy, 806-813. 